\title{
Contribution to the study of late cervical syringomyelic syndromes after dorsal or lumbar traumatic paraplegia
}

\author{
A. B. ROSSIER, A. WERNER, E. WILDI, AND J. BERNEY \\ From the Geneva University Cantonal Hospital, \\ Switzerland
}

Works dealing with a cervical syringomyelic syndrome of late appearance and at a distance from the initial traumatic cord lesion are few in number (Cossa, 1943; Freeman, 1959; Finkle, 1960; Jung, 1960; Schott, Trillet, Vauterin, and Koshbin, 1962; Martin and Maury, 1964; Riffat and Domenach, 1964; Bischof and Nittner, 1965; Barnett, Botterell, Jousse, and Wynn-Jones, 1966). The incidence of such complications being rare, between 1 and $1.5 \%$ (Martin and Maury, 1964; Barnett et al., 1966), we believe it interesting to report a similar case in order to describe in detail the nosological aspects of this affection. Of the 132 traumatic cord lesions that we have examined so far, we have not found another case.

\section{CASE HISTORY}

On 22 April 1965, the patient, a 15-year-old boy, fell from a height of $20 \mathrm{~m}$. He sustained a compression fracture of D6, D7, and D8 vertebrae with immediate paraplegia at D6 which remained complete. There was no loss of consciousness. Treatment was conservative.

Twelve months after the beginning of the paraplegia, the following was observed: the triceps reflex in the left arm had disappeared; there had been a rise in the level of the thermo-analgesia on the left side which had passed from D6 to D2, while a lack of feeling was evident in the left upper extremity; this was also of the syringomyelic type without motor deficit. The patient then revealed that for about two weeks he had had in the swimming-pool no appreciation of warmth in his left hand.

Air myelography (31 May 1966) (Dr. J. Berney) by the suboccipital and lumbar routes showed considerable widening of the cervical cord from $\mathrm{C3}$ to $\mathrm{C7}$, revealing in addition a fracture of the spinous process of $\mathrm{C7}$ that was confirmed later by histological examination (Figs. 1a and $\mathrm{b}$ ).

A laminectomy of C2 to C7 (10 May 1966) (Professor A. Werner) revealed diminution of the thickness of the laminae of C3, C4, and C5 and a distended dural sac without pulsation. The swollen spinal cord showed flattening of the roots along its sides; a cord torsion brought the emergence of the left posterior roots almost to the median line. The lateral columns showed a bluish colour in places and covered a cavity which extended from C3 to C7. Puncture caused shrinking of the cord and yielded 2-3 $\mathrm{ml}$ of clear yellowish liquid which did not coagulate. An incision over the dorsal median septum, at the height of $\mathrm{C5}$, made possible a penetration into the cavity. A little fragment of gutta percha was inserted in the incision to prevent it from closing (Dr. J. Berney).

Tables 1 and 2 and Figs. 2-6 illustrate the evolution of reflexes and of the sensory and muscle deficit before and after the operation.

\section{DISCUSSION}

SYMPTOMATOLOGY One of the first signs which often precede the appearance of the syringomyelic syndrome is pain-abdominal, thoracic, cervical, or at the level of the arms (Schott et al., 1962; Barnett et al., 1966).

In our case, we noted that one month before being aware of the thermanaesthesia in his left hand, our patient had complained of dorsal pains which were initially attributed to the muscular efforts of the motor re-education; they disappeared with massage in a few days but were followed two months later by neck pains. Moreover, palpation of the spinous process of C7 and D1 was painful. It is interesting to note that these pains disappeared after air myelography.

This painful symptomatology is accompanied by an ascending loss of sensation for temperature and pain which little by little reaches the cervical segments, sometimes even involving the trigeminal nucleus (Martin and Maury, 1964; Barnett et al., 1966). Accompanying or following the thermoanalgesia, by order of frequence and decreasing lesional importance, it seems that muscle power is first affected and then light touch and deep sensation. As a rule, at the level of the involved upper 
limbs, there is total or partial loss of reflexes. Although rarer, one may find signs of damage to the autonomic nervous system, such as Claude Bernard Horner's syndrome and uneven sweating; our patient was free of this as well as of any arthropathy (Martin and Maury, 1964; Barnett et al., 1966).

During the aggravation of the sensory deficit, it was first the sensitivity to temperature and pain that was the more affected and the more rapidly, whereas touch sensation deteriorated more slowly and less seriously; after the operation, the reverse appeared, tactile sensation improving first and more rapidly.

In most observations found in the literature, as well as in our case, between the initial cord level and the zone affected by the syringomyelic syndrome, there was no cutaneous area in which the different sensory modalities were all spared. However, in the few cases in which this was found (Schott et al., 1962), only the repetition of a complete neurological examination in the course of months would have been able to confirm or invalidate the persistence of its neurological integrity. During our first examination of 13 May 1966, it was difficult to ascertain if there were such a cutaneous normal area because of the proximity of the segments in question. Although on the left the thermaesthesia had risen to D1, the segments D2 and D3 seemed $\mathbb{D}$ to have maintained their sensitivity to touch, $\frac{c}{\circ}$ temperature, and pain. This was no longer the case in subsequent examinations. The progression $\widehat{a}$ of a pathological process within the cord cannot $D$ develop everywhere in a uniform manner (Holmes, 1915); thus, it must be possible to find in an intermediate area, according to the moment when $\stackrel{3}{\overrightarrow{2}}$ examination takes place, the presence of some sensory modalities.

The information yielded by myelography seems $\frac{0}{0}$ to be of variable value; of the seven myelographies of Barnett et al. (1966), four showed widening of $\bar{\omega}$ the cervical cord. However, one should bear in $\vec{\phi}$ mind the fact that not all authors have made this examination systematically. Moreover, the myelo- $\$$ graphic techniques vary, making comparison of $\overrightarrow{0}$ their results difficult. Nevertheless, it is especially $\overrightarrow{\vec{H}}$ air myelography, as was employed in our case, which should enable an early diagnosis to be made.

PATHOGENESIS The paucity of cases and especially $\dot{\omega}$ the rarity of operative reports and necropsies make all explanation of the aetiology of this syringog 6
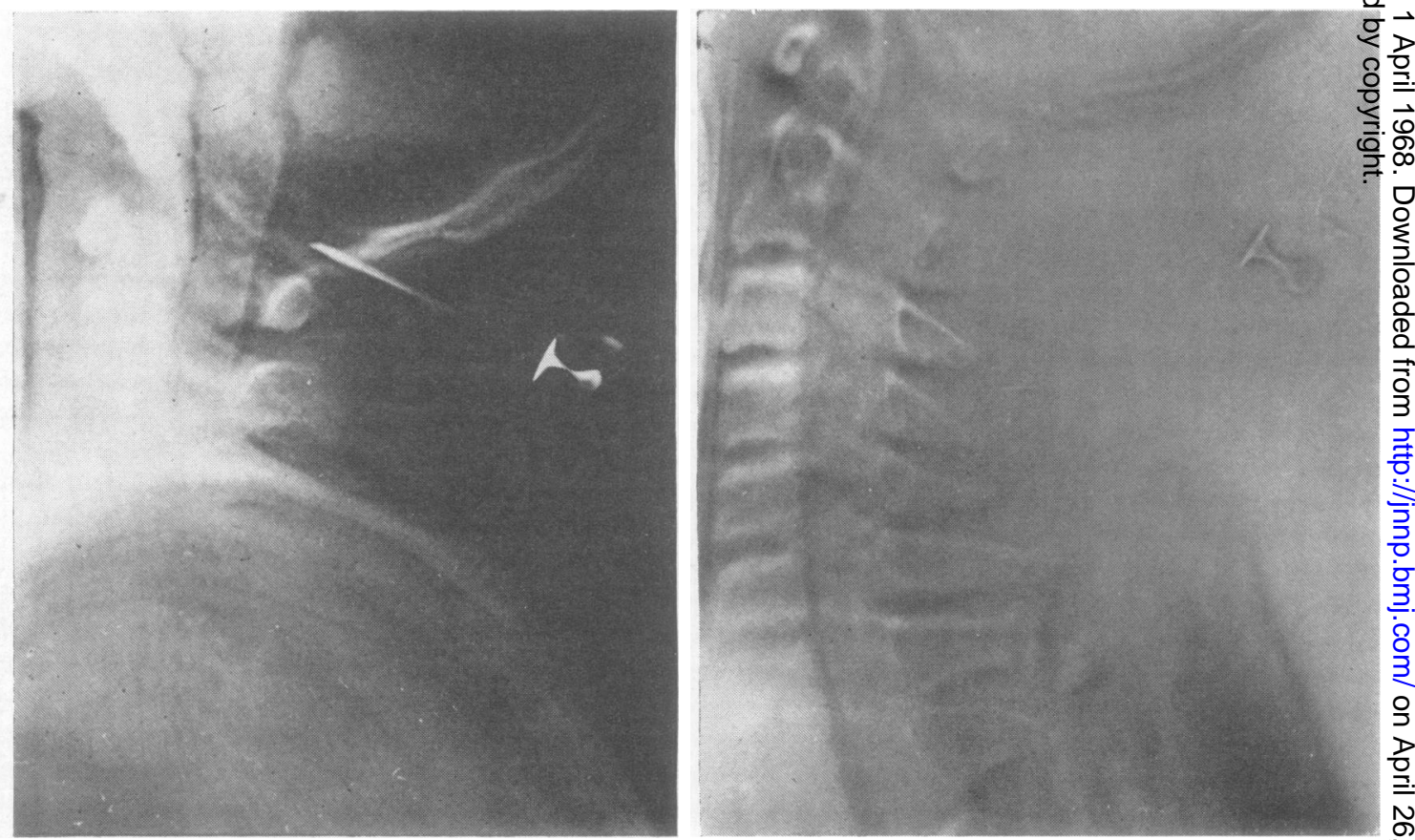

FIG. 1a. Air myelography showing widening of the cervical cord from C3 to C7.

FIG. 1b. Fracture of spinous process of $C 7$. 
TABLE I

CLINICAL DETAILS OF PATIENT ${ }^{1}$

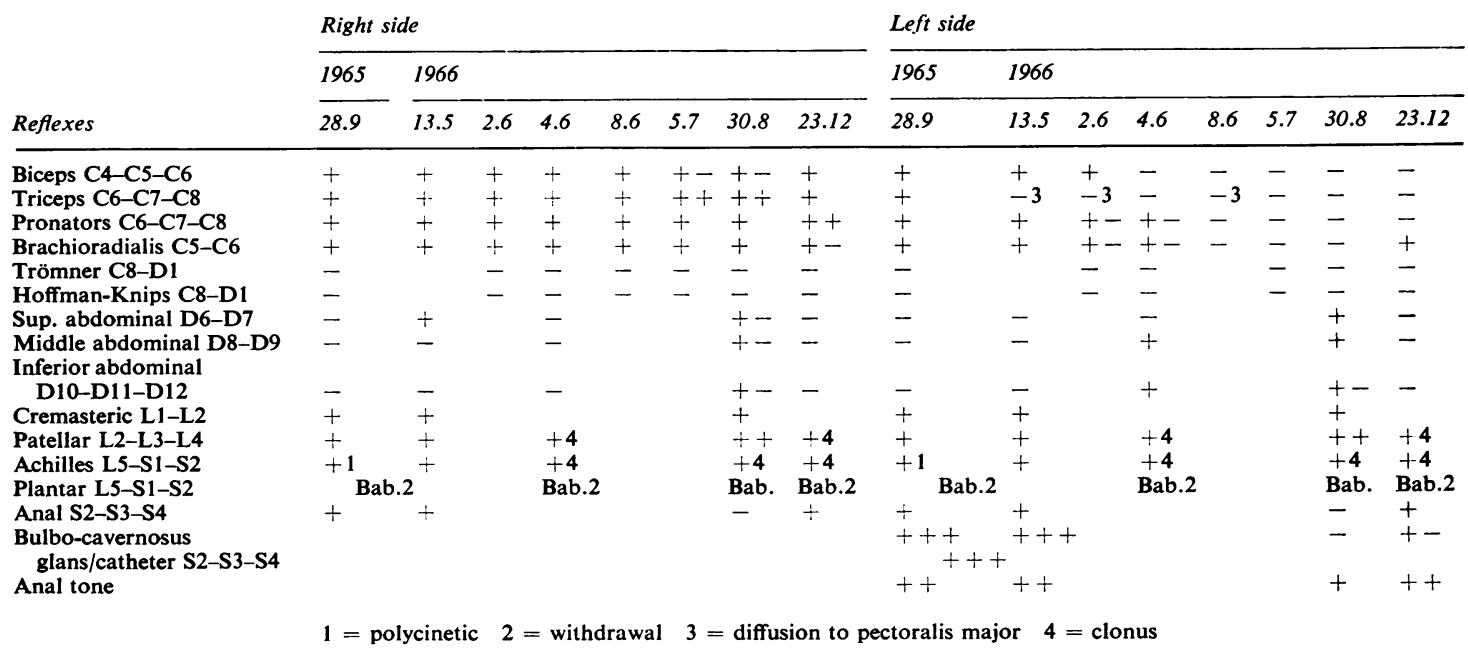

'Patient's name: de T. N. Date of birth: 14.5.1950. Diagnosis: spastic compl. traumatic myelopathy Th.6-Th.7 (22.4.1965). Appearance of neurological disturbances in the left upper extremity: end of A.pril 1966. Laminectomy: 10.6.1966.

myelic syndrome hypothetical. However, the operative status of our patient and the correspondence of the symptoms with those of the cases mentioned in the literature lead one to believe that it is a similar if not an identical pathological process.

A true syringomyelia does not seem probable. Its order of frequency, according to McIlroy and Richardson (quoted by Barnett et al., 1966), is $0.01 \%$ of the population of a large general hospital. The incidence of $1.3 \%$ mentioned by Martin and Maury (1964) and by Barnett et al. (1966), as well as our figure of $0.8 \%$, permit one practically to exclude this diagnosis. With the exception of the renal malformation of the case of Jung (1960), the absence of associated malformations, in particular of the spine and central nervous system, speaks in the same sense.

None of the authors cited has noticed any lesion of the cervical spine accompanying the initial dorsal or lumbar injury; it seems improbable that the fracture of the spinous process of $\mathrm{C} 7$ in our patient played a role in the formation of the cervical cavity. The evolution of the neurological deficit, ascending simultaneously from two different levels, cervical and dorsal, is also against such a hypothesis.

A syringomyelic syndrome can be explained only on the basis of an intramedullary lesion. Arachnoiditis per se cannot be considered-none was found when our patient was operated upon. However, it is known that it can become complicated by intramedullary cavitations.
The hypothesis of cavitation secondary to cervical hæmatomyelia occurring at the time of the initial accident must apparently be rejected. Traumatic hæmatomyelia is generally accompanied by immediate neurological symptoms and, in the course of the last few years, most histological examinations of spinal cord injuries have shown that it is more rare than was supposed. When the hæmorrhage within the cord is sufficiently severe, it can lead to the formation of round or oval cavities in the posterior columns with clinical features similar to those of true syringomyelia (Minor, 1904). According to Wolman (1965), these cavities could spread to numerous segments, even affecting the whole cervical cord and the upper dorsal cord. Such an aetiology cannot have existed in our case because of the absence of initial clinical signs at the cervical level; furthermore, in nervous parenchyme, organization of extravasated blood, pure or associated with necrosed tissue, is not, to our knowledge, accompanied by an oedematous reaction. When it results in the formation of cavities, the contents are not under increased pressure.

Among the remote effects of a cord trauma, there is the aggravation of a neurological deficit apparently stabilized. Marburg (1936) has stressed the possibility of late hæmorrhage and of secondary vascular changes, the 'traumatic vasopathies', likely to cause progressive cord lesions. These patches of softening can result in the formation of cavities, as can a patch of hæmatomyelia. They occur 

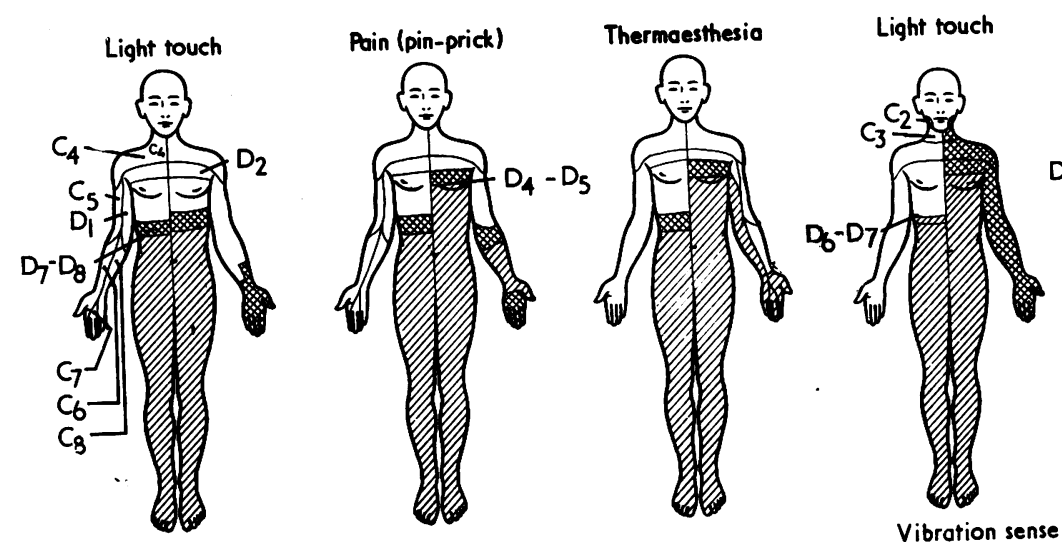

Poin (pin-prick)

Thermaesthesio $\left.\begin{array}{l}\text { Vibration sense } \\ \text { Joint position sense }\end{array}\right] \begin{aligned} & \text { no change at the upper left extrem compared with the right side } \\ & \text { as }\end{aligned}$

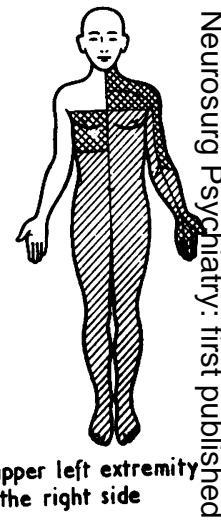

FIG. 2. Patient: de T.N. o 1950. Date of examination: 13 May, 1966. Examiner: $\mathrm{R} / \mathrm{He}$.

FIG. 3. Patient: de T.N. \& 1950. Date of examination: 24 May, 1966. Examiner: R/He.
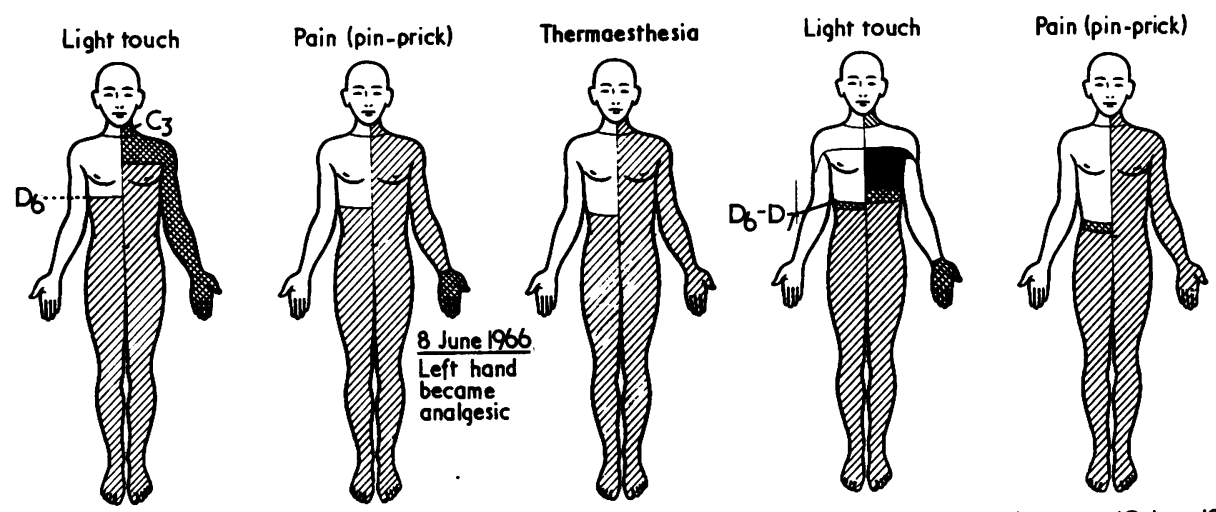

Lominectomy 10 June 1966

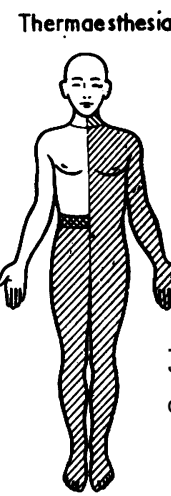

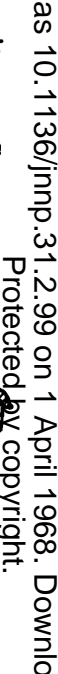

FIG. 4. Patient: de T.N. $\delta$ 1950. Date of examination. 2 June, 1966. Examiner: $R / H e$.
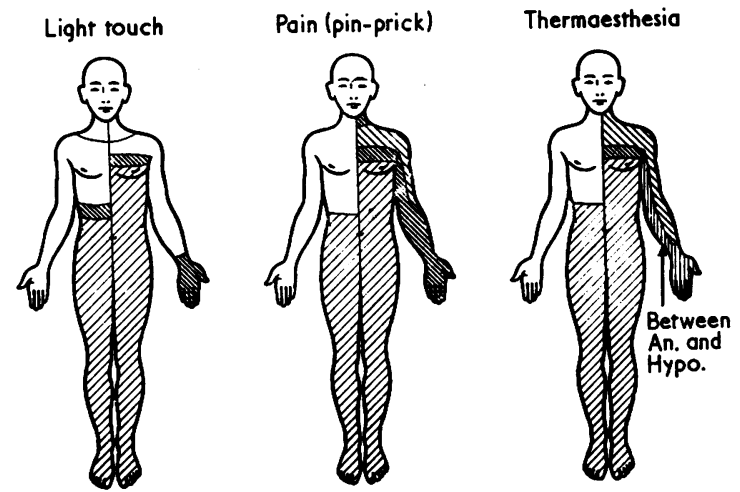
FIG. 5. Patient: de T.N.
21 June, 1966. Examiner: He.

FIG. 6. Patient: de T.N. \& 1950. Date of examination: 23 December, 1966. Examiner: $R$.

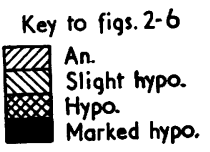


most commonly in the posterior horns and columns but may also be found near the central canal, at the level of the anterior horns. They are accompanied by a syringomyelic symptomatology. In our case, should a process ending in a myelomalacia have developed, one could explain the enlargement of the spinal cord only by the formation of a cavity with an increase of its internal pressure. This intracavital hypertension could result from changes in the colloido-osmotic (oncotic) pressure by a mechanism comparable to the one proposed by Zehnder (1937) to explain some late clinical symptoms of chronic subdural hæmatoma.

With war-wounded patients Holmes (1915) found paramedian cavities above and/or below the initial lesion, at the level of the posterior columns and usually unilateral. According to this author, neither the grey matter, with the exception of one of his cases, nor the ependymal canal, was affected. These cavities remained generally connected to the initial cord lesion by a small track of oedematous tissue or by a fissure, and must have contained liquid under pressure since they compressed the adjacent structures. Holmes (1915) thought that they developed from the accumulation of a transudate and of products of tissue degeneration which could be seen in serial sections.

After cord trauma, Minor (1904) noted changes in the vascular walls in the form of a hyaline degeneration with fatty degeneration of the endothelium. He also noted oedema of the vascular walls sufficient to obliterate the lumen or even to cause thrombosis of the vessel. If to the primary condition of tissue necrobiosis there be added secondary disturbances due to local circulatory insufficiency, it would seem that a sufficient number of circumstances would be gathered to cause secondary cavitations. In some cases the reversibility of the initial neurological symptoms is traditionally attributed to regression of post-traumatic cord

TABLE II

MUSCLE TEST CARRIED OUT IN $1966^{1}$

\begin{tabular}{|c|c|c|c|c|c|c|c|c|c|c|c|c|c|}
\hline & & \multicolumn{6}{|c|}{ Right } & \multicolumn{6}{|l|}{ Left } \\
\hline & & 3.6 & 8.6 & 21.6 & 7.7 & 30.8 & 23.12 & 3.6 & 8.6 & 21.6 & 7.7 & 30.8 & 23.12 \\
\hline Shoulder-blade & $\begin{array}{l}\text { Serratus } \\
\text { Trapezius sup. } \\
\text { Trapezius inf. } \\
\text { Trapezius middle } \\
\text { Rhomboides }\end{array}$ & $\begin{array}{l}5 \\
5 \\
5 \\
5\end{array}$ & & $\begin{array}{l}5 ? \\
5 ? \\
5 ? \\
5\end{array}$ & $\begin{array}{l}5 \\
5 \\
5\end{array}$ & $\begin{array}{l}5 \\
5 \\
5\end{array}$ & $\begin{array}{l}5 \\
5 \\
5 \\
5\end{array}$ & $\begin{array}{l}5 \\
5 \\
4+ \\
4+\end{array}$ & & $\begin{array}{l}5 ? \\
5 ? \\
5 ? \\
4+\end{array}$ & $\begin{array}{l}4+ \\
5 \\
4 \\
4\end{array}$ & $\begin{array}{l}4+ \\
5 \\
4+ \\
4+\end{array}$ & $\begin{array}{l}5 \\
5 \\
5 \\
5\end{array}$ \\
\hline Shoulder & $\begin{array}{l}\text { Deltoides ant. } \\
\text { Latissimus dorsi } \\
\text { Teres major }\end{array}$ & 5 & & $\begin{array}{l}5 \\
4\end{array}$ & $\begin{array}{l}5 \\
5\end{array}$ & $\begin{array}{l}5 \\
5\end{array}$ & $\begin{array}{l}4+ \\
4\end{array}$ & $\begin{array}{l}5 \\
4\end{array}$ & & $\begin{array}{l}4+ \\
3\end{array}$ & $\begin{array}{l}4 \\
2+\end{array}$ & $\begin{array}{l}4+ \\
3\end{array}$ & $\begin{array}{l}4+ \\
3\end{array}$ \\
\hline & $\begin{array}{l}\text { Deltoides middle } \\
\text { Deltoides post. } \\
\text { Pectoralis major } \\
\text { Ext. rotat. } \\
\text { Int. rotat. }\end{array}$ & $\begin{array}{l}5 \\
5 \\
5 \\
5 \\
5\end{array}$ & & $\begin{array}{l}5 \\
5 \\
4+ \\
5 \\
5\end{array}$ & $\begin{array}{l}4+ \\
4+ \\
5 \\
5 \\
5\end{array}$ & $\begin{array}{l}5 \\
5 \\
5 \\
5 \\
5+\end{array}$ & $\begin{array}{l}4+ \\
4+ \\
5 \\
5 \\
5\end{array}$ & $\begin{array}{l}4+ \\
5 \\
4+ \\
5 \\
5\end{array}$ & & $\begin{array}{l}4 \\
4 \\
4 \\
4+ \\
4+\end{array}$ & $\begin{array}{l}3 \\
3+ \\
4 \\
4 \\
4\end{array}$ & $\begin{array}{l}3 \\
4 \\
4+ \\
4 \\
4\end{array}$ & $\begin{array}{l}3+ \\
3+ \\
4+ \\
4+ \\
4+\end{array}$ \\
\hline Elbow & $\begin{array}{l}\text { Triceps } \\
\text { Biceps } \\
\text { Brachioradialis }\end{array}$ & 5 & & 4 & $\begin{array}{l}4+ \\
4\end{array}$ & $\begin{array}{l}5 \\
5\end{array}$ & $\begin{array}{l}5 \\
5\end{array}$ & $\begin{array}{l}4+ \\
5\end{array}$ & & 4 & $\begin{array}{l}4 \\
5\end{array}$ & $\begin{array}{l}4+ \\
4\end{array}$ & $5-$ \\
\hline Forearm & $\begin{array}{l}\text { Supinators } \\
\text { Pronators }\end{array}$ & 4 & & 4 & 5 & 5 & 5 & $\begin{array}{l}5 \\
4+\end{array}$ & & $\begin{array}{l}4 \\
4\end{array}$ & $4+$ & 4 & $\begin{array}{l}4+ \\
4+\end{array}$ \\
\hline Wrist & $\begin{array}{l}\text { Flexor carpi radialis } \\
\text { Flexor carpi ulnaris } \\
\text { Extensor carpi radialis longus } \\
\text { Extensor carpi radialis brevis } \\
\text { Extensor carpi ulnaris }\end{array}$ & 5 & 5 & $4+$ & 5 & $\begin{array}{l}5 \\
5\end{array}$ & 5 & $\begin{array}{l}4+ \\
4 \\
4+\end{array}$ & $\begin{array}{l}4+ \\
4 \\
4+\end{array}$ & $\begin{array}{l}4 \\
4 \\
4\end{array}$ & $\begin{array}{l}4+ \\
4-\end{array}$ & $\begin{array}{l}4+ \\
4 \\
3+\end{array}$ & $\begin{array}{l}5 \\
4 \\
4+\end{array}$ \\
\hline Fingers & $\begin{array}{l}\text { Lumbricales } \\
\text { Flexor digitorum superficialis } \\
\text { Flexor digitorum profundus } \\
\text { Extensor digitorum communis } \\
\text { Interossei palm. }\end{array}$ & $\begin{array}{l}5 \\
5 \\
5 \\
5 \\
5\end{array}$ & $\begin{array}{l}4+ \\
4+ \\
5 \\
5 \\
5\end{array}$ & $\begin{array}{l}5 \\
5 \\
5 \\
5 \\
5\end{array}$ & $\begin{array}{l}5- \\
4- \\
5 \\
5 \\
5\end{array}$ & $\begin{array}{l}5 \\
5\end{array}$ & $\begin{array}{l}5 \\
4+ \\
5 \\
5 \\
5\end{array}$ & $\begin{array}{l}4 \\
4 \\
5 \\
4+ \\
4\end{array}$ & $\begin{array}{l}3+ \\
3+ \\
4 \\
4 \\
4\end{array}$ & $\begin{array}{l}4 \\
4 \\
4+ \\
4 \\
4\end{array}$ & $\begin{array}{l}3+ \\
3+ \\
\mathbf{4} \\
\mathbf{3}+ \\
\mathbf{3}-\end{array}$ & $\begin{array}{l}3+ \\
4 \\
4+ \\
3+ \\
3+\end{array}$ & $\begin{array}{l}4+ \\
4+ \\
5 \\
4 \\
4 \\
3+\end{array}$ \\
\hline & $\begin{array}{l}\text { Interossei dors. } \\
\text { Abductor quinci } \\
\text { Opponens quinci }\end{array}$ & $\begin{array}{l}5 \\
5 \\
5\end{array}$ & $\begin{array}{l}5 \\
5 \\
5\end{array}$ & $\begin{array}{l}5 \\
5 \\
5\end{array}$ & $\begin{array}{l}5 \\
5 \\
5\end{array}$ & & $\begin{array}{l}5 \\
5 \\
4+\end{array}$ & $\begin{array}{l}4+ \\
4+ \\
4\end{array}$ & $\begin{array}{l}4 \\
4+ \\
4\end{array}$ & $\begin{array}{l}4 \\
4 \\
4\end{array}+$ & $\begin{array}{l}3 \\
4 \\
4\end{array}$ & $\begin{array}{l}3+ \\
3+ \\
3\end{array}$ & $\begin{array}{l}4 \\
4\end{array}$ \\
\hline Thumb & $\begin{array}{l}\text { Flexor pollicis brevis } \\
\text { Flexor pollicis longus } \\
\text { Extensor pollicis brevis } \\
\text { Extensor pollicis longus } \\
\text { Abductor pollicis brevis } \\
\text { Abductor pollicis longus } \\
\text { Adductor pollicis } \\
\text { Opponens pollicis }\end{array}$ & $\begin{array}{l}5 \\
5 \\
5 \\
5 \\
5 \\
5 \\
5 \\
5\end{array}$ & $\begin{array}{l}4+ \\
5 \\
5 \\
5 \\
5 \\
5 \\
5 \\
4+\end{array}$ & $\begin{array}{l}5 \\
5 \\
5 \\
5 \\
5 \\
5 \\
5 \\
5\end{array}$ & $\begin{array}{l}5 \\
5 \\
5 \\
5 \\
5 \\
5 \\
5 \\
5\end{array}$ & & $\begin{array}{l}5 \\
5 \\
5 \\
5 \\
5 \\
5 \\
5 \\
5\end{array}$ & $\begin{array}{l}4+ \\
4+ \\
4+ \\
4+ \\
4+ \\
4+ \\
4+ \\
3+\end{array}$ & $\begin{array}{l}4 \\
4 \\
4+ \\
4+ \\
4 \\
4 \\
4 \\
3+\end{array}$ & $\begin{array}{l}4+ \\
4+ \\
4+ \\
4+ \\
4+ \\
4 \\
4+ \\
4\end{array}$ & $\begin{array}{l}4 \\
4 \\
4 \\
4 \\
4 \\
4 \\
4 \\
4\end{array}$ & $\begin{array}{l}4 \\
4 \\
4 \\
4 \\
4 \\
4 \\
3 \\
4\end{array}$ & $\begin{array}{l}4 \\
4+ \\
4+ \\
4+ \\
4+ \\
4 \\
4 \\
4+\end{array}$ \\
\hline
\end{tabular}

${ }^{1}$ Testing according to the nomenclature of the British Medical Research Council in 1943. 
oedema; however, there are oedemas which are accompanied by destruction of the myelin sheaths and axis cylinders. This process is then identified with myelomalacia (Marburg, 1936) and corresponds to what Jellinger (1966) has called 'atypische Oedemnekrosen', the characteristic of which is not organization but liquefaction. Marburg (1936) has explained the late appearance of the syringomyelic syndrome by the fact that necrobiosis develops slowly. Cavitation could evolve silently until its volume has become sufficient to cause compression of the adjacent structures.

Zülch (1962) has explained the 'pencil-like' necrosis on the basis of a circulatory insufficiency at the level of the arteriae coronae. This ischaemic necrosis would occur more easily in watershed areas between two different vascular territories as at the level of D4-D5. Likewise, an insufficient irrigation of the watershed area depending on the posterior spinal arterial system and the branches of the anterior spinal artery could explain necrosis at the level of the posterior horns or of the posterior grey commissure, the grey matter being affected first because of its greater need of oxygen. It is possible that a vascular pathology may be not only arterial but also venous in origin, local circulatory disturbances giving rise to stasis and hence necrosis (Jellinger, 1966). In both cases resorption of the necrotic tissue could result in secondary formation of cavities.

Whether it is a question of the aggravation of the neurological symptoms or of their post-operative improvement, their simultaneous evolution from two different levels, cervical and dorsal, over several segments, would suggest the possibility of an anatomo-pathological continuity between them. Rather than postulate a pathogenesis sui generis, one could postulate that the pathological process has its origin at the level of or above the initial cord lesion; it would reveal itself only after very variable lapses of time, from four months to 16 years (Martin and Maury, 1964; Barnett et al., 1966).

LOCALIZATION OF THE PATHOGENIC PROCESS At operation our patient showed unilateral cystic formation at the site of the left lateral columns. The neurological evolution suggested an expanding and non-destructive process. In the left upper limb a rapid involvement of thermal sensation was found at first, followed more slowly by a less severe impairment of tactile appreciation. After the laminectomy recovery was in the reverse order. As for the motor effects, it was noted that at the beginning paresis affected hand muscles more than those of the rest of the arm. Finally, there was an almost complete absence of impairment of the gnostic sense. All of these elements suggest cavitation in the grey or white matter at the base of the left posterior horn, near the rubrospinal tract and the lateral corticospinal tract. Only these two localizations could explain the loss of sensation for temperature and pain on the same side as the anatomical lesion observed at operation. The unilateral deficit spoke against a lesion in the region of the central canal. These two localizations could also explain the repercussion of the compression on the fibres of the lateral corticospinal tract, the innermost fibres of which are related to the upper limbs, and on the motor cells of the anterior horns where cells corresponding to the muscles of the hand occupy the most dorsolateral portion (Crosby, Humphrey, and Lauer, $\bullet 1962)$. The almost complete absence of gnostic involvement could be explained by the anatomical localization of the lesion which exerted its compressive effects on the nearest tissues-that is, the lateral pyramidal tract and/or the grey matter cells. The latter because of their looser consistency are more sensitive than the white matter to an expanding process.

\section{CONCLUSIONS}

Present knowledge does not permit definite conclusions as to the precise pathogenesis of these late syringomyelic syndromes. However, it permits some hypotheses based on clinical facts and on operative records and necropsies. At the initialo stage, two main aetiological factors can be taken? into account, hæmatomyelia, which is infrequent, and myelomalacia through local circulatory disorders. At the final stage, one or several intramedullary cavitations form, at first in the posterior columns and horns. The common clinical result of this is a syringomyelic syndrome. However, in our case, one may imagine that an oedema of undetermined cause-insidious and slow to progress-was the origin of the imbalance of the interstitial tissue pressure and it is not necessary to involve a malacic process. The slowness of tissue necrobiosis on the one hand, and, on the other, the necessity of having a cyst of sufficient volume to exert compression on the adjacent structures can explain the late appearance of the new neurological symptoms. At the beginning it is not a very destructive process. The considerable post-operative regression of the neurological deficit in our case and in the patients of Freeman (1959) and Finkle (1960) proves this. Left to itself, the evolution of symptoms can reach a plateau or even show spontaneous regression. Sometimes, however, it can be dramatic and lead to tetraparesis (cf. case no. 2 of Barnett et al., 1966). 
We therefore think that such a syndrome requires surgical intervention when the myelography reveals widening of the spinal cord. This statement seems to be justified by the success of surgery in our patient and in the cases of Freeman (1959) and Finkle (1960). The 12-month post-operative followup of our patient does not yet allow us to conclude that definite improvement has taken place but it has to be remembered that each of the imposed cases of Freeman (1959) and Finkle (1960) had a follow-up of two years' duration.

As the syringomyelic syndrome often manifests itself initially in the upper limbs, the sudden appearance of unexplained pain suggesting a lesion at the thoracic or cervical level should indicate repetition of the neurological examination in the course of the following weeks or months.

\section{SUMMARY}

On the basis of the detailed pre- and post-operative clinical evolution of one of their patients, the authors discuss within the framework of the cases published up to the present time, the symptomatology, pathogenesis, prognosis, and therapy of late cervical syringomyelic syndromes, the anatomical lesion of which appears to be situated at a distance from the initial dorsal or lumbar traumatic cord lesion. An hypothesis on the anatomical localization of the pathological cavitation is advanced.

We would like to express our thanks to Mr. C. Ryser, medical artist to the Faculty of Medicine of the University of Geneva, for having so kindly undertaken to prepare the figures and graphs for this work.

\section{REFERENCES}

Barnett, H. J. M., Botterell, E. H., Jousse, A. T., and Wynn-Jones, M. (1966). Progressive myelopathy as a sequel to traumatic paraplegia. Brain, 89, 159-1 74 .

Bischof, W., and Nittner, K. (1965). Zur Klinik und Pathogenese der vaskulär bedingten Myelomalazien. Neurochirurgia, 8 , 215-231.

Cossa, P. (1943). Syringomyélie secondaire à une blessure de la moelle dorsale supérieure. Rev. Neurol., 75, 39-40.

Crosby, E. C., Humphrey, T., and Lauer, E. W. (1962). Correlative Anatomy of the Nervous System. MacMillan, New York.

Finkle, J. R. (1960). Lesions ascending from spinal cord injuries. In Proc. ninth Ann. Clin. Spinal Cord Injury Confr., pp. 45-48. Veterans Administration Hospital, Long Beach, California.

Freeman, L. W. (1959). Ascending spinal paralysis. Case presentation. J. Neurosurg., 16, 120-122.

Holmes, G. (1915). The Goulstonian lectures on spinal injuries of warfare. I. The pathology of acute spinal injuries. Brit. med.J., 2, 769-774.

Jellinger, K. (1966). Zur Orthologie und Pathologie der Rückenmarksdurchblutung. Springer, Vienna.

Jung, E. (1960). Syringomyelie in Kombination mit Entwicklungsstörung der Nieren und mit schwerer Wirbelsäulenverletzung. Med. Klinik., 55, 1678-1679.

Marburg, O. (1936). Die traumatischen Erkrankungen des Gehirns und Rückenmarks. In Handbuch der Neurologie, edited by O. Bumke and O. Foerster. Vol. 11; Spezielle Neurologie. III. Erkrankung des Rückenmarks und Gehirns. I. Traumatische präsenile und senile Erkrankungen Zirkulationsstörungen. Springer, Berlin.

Martin, C., and Maury, M. (1964). Syndrome syringomyélique après paraplégie traumatique. A propos de six cas de syndrome syringomyélique cervical survenant dans des paraplégies dorsale ou lombaire. Presse méd., 72, 2839-2842.

McIlroy, W. J. and Richardson, J. C. Quoted by Barnett et al. (1966),

Minor, L. (1904). Traumatische Erkrankungen des Rückenmarkes. (Rückenmarks-Zerquetschung, Hämatomyelie, Nekrose etc.). In Handbuch der pathologischen Anatomie des Nervensystems, Vol. 2, edited by E. Flatau, L. Jacobson, and L. Minor. pp. 1008-1058. Karger, Berlin.

Riffat, G., and Domenach, J. (1964). Syndrome syringomyélique succédant à un traumatisme médullaire ancien. Lyon Méd., $212,1043$.

Schott, B., Trillet, M., Vauterin, C., and Koshbin. (1962). Syndromes syringomyéliques tardifs sus-lésionnels après traumatisme médullaire (à propos de trois observations cliniques). Rev. Neurol., 106, 751-755.

Wolman, L. (1965). The disturbance of circulation in traumatic paraplegia in acute and late stages: a pathological study. Paraplegia, 2, 213-226.

Zehnder, M. (1937). Die subduralen Hämatome. Zbl. Neurochir., 2, 339-353.

Zülch, K. J. (1962). Réflexions sur la physiopathologie des troubles vasculaires médullaires. Rev. Neurol., 106, 632-645.

\section{ADDENDUM}

Since this article was submitted for publication, another similar case has come to our attention. The patient was born in 1912. There was a traumatic complete cord lesion D8 in June 1956 (fractures D8 and D9). In March 1959 a syringomyelic syndrome appeared on the right side. The symptoms progressed very slowly until the patient was first seen in our centre in March 1967 with an upper neurological limit at C3. A neurological condition was found similar to that of our first case. Air myelogram showed a considerable enlargement of the cord extending from C3 to D7. A laminectomy (9 August 1967) from $C 7$ to $D 3$ with a median posterior cord incision showed a cystic cavity in communication with the fourth ventricle. Protein content was $1160 \mathrm{mg} / \mathrm{l}$. in the spinal fluid and $286 \mathrm{mg} / \mathrm{l}$. in the hydromyelic cavity. Two months after the operation the patient had made such a recovery that sensory and motor conditions were almost normal. 